\title{
THE EFFECTS OF BIODIESEL ON NOx EMISSIONS FOR AUTOMOTIVE TRANSPORT
}

\author{
Ruslana Kolodnytska ${ }^{1}$, Oleksandr Kravchenko ${ }^{1}$, Juraj Gerlici' ${ }^{2}$, Kateryna Kravchenko ${ }^{2}$ \\ ${ }^{1}$ Zhytomyr Polytechnic State, Zhytomyr, Ukraine \\ ${ }^{2}$ University of Zilina, Zilina, Slovak Republic \\ *E-mail of corresponding author: kateryna.kravchenko@fstroj.uniza.sk
}

\section{Resume}

Automobiles with internal combustion engine using diesel fuel have large harmful emissions of nitrogen oxides and soot, which affect the health of the population and especially children and carbon dioxide, which is dangerous for the planet as a whole. Biodiesel is used in Europe as an additive to diesel fuel to reduce soot emissions (including carcinogens), as well as to improve the balance of carbon dioxide on the planet. Using the biodiesel in internal combustion engines tends to show higher nitrogen oxides emissions compared to diesel. In this paper, the impact of flame temperature, ignition delay and density on NOx formation of biodiesel and its component for both stationary engine and automotive engine were analysed. Emissions of nitrogen oxides increase with increasing load. In no-load modes, biodiesel shows lower emissions of nitrogen oxides than diesel.

\section{Article info}

Received 17 June 2021

Accepted 8 July 2021

Online 4 November 2021

\section{Keywords:}

automotive transport, nitrogen oxides, biodiesel, ignition delay, flame temperature

\section{Introduction}

Developing promising methods to reduce the environmental impact of the road transport on environment [1-7], scientists are making great efforts to ensure that transport is "green". Automobiles using diesel fuel have large harmful emissions of nitrogen oxides and soot, which affect the health of the population and especially children and carbon dioxide, which is dangerous for the planet as a whole.

The ban on diesel engines in some European countries leads to the fact that automobiles with these engines are more sold and used in Ukraine. At the moment, in Ukraine most of the buses with diesel engines are more than 10 years old.

Biodiesel is used in Europe as an additive to diesel fuel in order to reduce soot emissions as well as carcinogens. Biofuels made from used vegetable oil and animal fat residues are used in London; there are 9,500 buses in the UK. The UK has begun using biodiesel made from coffee residues as fuel for city buses. To operate one bus on biofuel (B20) mixed with diesel fuel, only 2,550,000 cups of coffee are needed per year. Biofuels consumption for transport in Slovakia peaked at 175.4 kilotons of oil equivalent in 2017 [8]. By 2019, it decreased by 30 kilotons of oil equivalent. At that time, the country's biodiesel consumption was at 127.9 kilotons of oil equivalent [8]. The amount of bioethanol consumed was significantly smaller compared to biodiesel.
Since biodiesel has higher nitrogen oxide emissions, modeling nitrogen oxide emissions from road transport is a very important task. It is impossible to solve this problem without understanding the processes occurring in internal combustion engines.

\section{Analysis of previous research}

The theoretical and experimental study of nitrogen oxide emissions from use of the diesel fuel and biodiesel in diesel engine was considered by scientists in [9-19]. Analysis of influence of factors on nitrogen oxide emissions when using fuels containing oxygen, made in [9]. In [10], the influence of individual molecules, from which biodiesel is composed, on emissions of nitrogen oxides is considered. Some aspects of spraying, evaporation and combustion of biodiesel are shown in [11-17].

Emissions of nitrogen oxides are highly dependent on the temperature in the combustion chamber, as well as on the concentration of oxygen that is present in the combustion products [18]. Higher emissions of nitrogen oxides from biodiesel are mainly because this fuel usually has a slightly lower ignition delay than diesel fuel. This shorter ignition delay increases the maximum cylinder temperatures and pressures. All this is due to the higher cetane number of fuel, which usually biodiesel has, compared to diesel. 
Table 1 Emissions of nitrogen oxides for diesel fuel (D2) and its mixture with biodiesel fuel (B35) for various cycles (DDC series 60)

\begin{tabular}{cccccc}
\hline & WVU truck cycle & \multicolumn{3}{c}{ WVU 5-mi route cycle } \\
\hline B35 & D2 & $\%$ & B35 & D2 & $\%$ \\
16.597 & 16.957 & 2.123017 & 16.631 & 17.986 & 7.533637 \\
\hline
\end{tabular}

Studies [18] carried out with Cummins engines for the B35 mixture show that nitrogen oxides when using biodiesel fuel increase only for relatively old engine models (for example, Cummins 855). For the newer engine models (DDC series 60), nitrogen oxide emissions were slightly lower for biodiesel than for diesel. Nitrogen oxide emissions were different for different test cycles of trucks with engines, shown in Table 1.

It was shown in [10] that at the same injection time, molecules with long chains of fatty acids had higher emissions of nitrogen oxides than molecules with short chains. Some molecules tend to form large emissions of particulate and nitrogen oxides. For example, this was observed in the case of unsaturated molecules (with double bonds), when both $\mathrm{NOx}$ and particle emissions increased with an increase in the degree of unsaturation [10, 16]. Experiments [16] have shown that polyunsaturated methyl ester (C18:3) produces the largest amount of nitrogen oxides, which once again confirms the fact that molecules with a longer ignition delay produce more nitrogen oxides. Thus, experiments show that nitrogen oxide emissions increase with the number of double bonds unless the ignition delay is deliberately changed.

As known, for a constant load (whether it is a fixed start of injection or the start of combustion), the ignition delay is correlated with NOx emissions. However, the mechanism of this influence is not yet fully understood. Optical diagnostics [10] showed that nitrogen oxides are formed not at the early fast stages of combustion (premixed combustion phase), but at a later stage of diffusion combustion. Some researchers believe that the rapid combustion of enriched fuels at low temperatures results in significant emissions of nitrogen oxides. It has also been shown that when a large proportion of the fuel is burned during a fast initial combustion mode, it can lead to an increase in the global temperature of the gas in the cylinder, leading to more formation of nitrogen oxides.

Fuel viscosity has a significant impact on NOx emissions. Analysis of scientific works, where NOx emissions were analyzed as a function of viscosity and an increase in NOx with increasing viscosity at low temperatures was revealed in [16]. Since the kinematic viscosity of biodiesel is greater than that of diesel fuel, this reduces fuel leaks during the injection and results in higher pressure, as well as advanced injection times. Advancement of the injection time increases the mass of fuel injected, which, in turn, leads to an increase in NOx emissions. Thus, it is possible to achieve a reduction in NOx emissions by about $3.52 \%$ at a reduced viscosity of soy methyl ester to the level of petroleum diesel fuel [16].

Although the number of publications on diesel fuel has grown exponentially over the past 15 years, little attention has yet been paid to study of influence of various factors on the nitrogen oxide emissions from fuel combustion.

\section{Formulation of the problem}

To reduce harmful emissions from motor vehicles with internal combustion engines, a deep understanding of the spontaneous combustion processes and combustion of fuel is required. Fuel self-ignition is characterized by the two main parameters: the initial temperature (the minimum temperature at which the fuel can selfignite) and the ignition delay (the time between the fuel injection and ignition). Those parameters depend on the pressure in the combustion chamber, the type and chemical composition of the fuel, etc. The chemical kinetics of spontaneous combustion includes about 1000 chemical reactions and about a hundred fuel components. An additional difficulty is that the rate coefficients of all the reactions are not known and the solution to this problem requires a lot of time and finance since it is often associated with use of a powerful computer. Researchers are working to reduce the number of equations describing the combustion of diesel fuel in internal combustion engines.

In order to tackle the problem of reducing the NOx emissions from biodiesel for road transport, it is important to have a deep understanding of factors that influence these emissions and the ability to manage them.

The purpose of this work was to analyze influence of various factors on formation of the nitrogen oxides in the internal combustion engine of motor vehicles when using biodiesel. The objective of this work was to determine correlations between the nitrogen oxide emissions, fuel density, flame temperature and fuel ignition delay.

\section{Influence of various factors on formation of nitrogen oxides}

The NO emissions from the combustion of fuel in an internal combustion engine can be calculated using the following equation [9]:

$\frac{d[N O]}{d t}=2 k[O]\left[N_{2}\right]$, 
Table 2 Temperatures of adiabatic flame $T_{a d}$ for fuels and their components

\begin{tabular}{cccc}
\hline Fuels & $(\mathrm{C} / \mathrm{H})_{\text {eff }}$ & $\mathrm{T}_{\mathrm{ad}}, \mathrm{K}$ \\
\hline $\mathrm{C} 16: 0$ & 0.463 & 2660 \\
$\mathrm{C} 18: 0$ & 0.467 & 2665 \\
$\mathrm{C} 18: 1$ & 0.492 & 2670 \\
$\mathrm{C} 18: 2$ & 0.493 & 2680 \\
$\mathrm{C} 18: 3$ & 0.522 & 2700 \\
$\mathrm{~B} 100$ & 0.522 & - \\
$\mathrm{D} 2$ & 0.552 & 2700 \\
\hline
\end{tabular}

where:

$[N O]$ is the nitric oxide concentration,

$[\mathrm{O}]$ is the atomic oxygen concentration,

$\left[N_{2}\right]$ is the molecule nitrogen concentration,

$k$ is the reaction rate coefficient.

The reaction rate coefficient can be described using the Arrhenius equation as

$k=A T^{\beta} \exp \left[-E /\left(R_{O} T\right)\right]$

where:

$E$ is the activation energy,

$R_{O}$ is the universal gas constant,

$R_{O}=8-314\left[\mathrm{~J} \cdot \mathrm{mol}^{-1} \cdot \mathrm{K}^{-1}\right]$

$T$ is the temperature,

$A$ and $\beta$ are constants.

Due to its strong temperature dependence, the thermal NO emissions are largely ignored at temperatures less than $1800 \mathrm{~K}$. Müller et al. [9] note that the thermal NOx emissions tend to increase with increasing the in-cylinder temperature, residence time of the mixture in the cylinder at high temperature, the concentration of oxygen atoms $\mathrm{O}_{2}$ and nitrogen $\mathrm{N}_{2}$.

This paper analyzes influence of the flame temperature, fuel density and fuel ignition delay on the thermal formation of $\mathrm{NOx}$ in an internal combustion engine.

\subsection{Influence of the flame temperature}

As a rule, the gases temperature in the engine cylinder is estimated using the ideal gas equation, for example, in [9]:

$T=\frac{p V}{n R_{O}}$,

where:

$p$ is the ambient pressure,

$V$ is the cylinder volume,

$n$ is the number of moles,

$R_{O}$ is the universal gas constant.

Inflame adiabatic temperature is understood as the temperature of a mixture during combustion at constant pressure without converting heat and without changing the kinetic or potential energy. This temperature for hydrocarbon fuels is closely related to the $\mathrm{C} / \mathrm{H}$ ratio. If this ratio increases, then the flame temperature also increases. The $\mathrm{CO}_{2}$ formation requires more energy than $\mathrm{H}_{2} \mathrm{O}$ formation. Thus, the $\mathrm{C} / \mathrm{H}$ ratio can be used to describe the influence of hydrocarbon composition (including double bonds) on flame temperature. However, for biodiesel fuels, this ratio may be less accurate. Müller et al. [9] recommended using the following ratio for fuels containing oxygen:

$$
\frac{C}{H_{e f f}}=\frac{C-\frac{1}{4} O_{-}-\frac{1}{2} O_{=}}{H},
$$

where $\mathrm{O}$ and $\mathrm{O}_{=}$is the number of oxygen atoms with single and double bonds, respectivly.

Using Equation (4), $(\mathrm{C} / \mathrm{H})_{\text {eff }}$ is 0.552 and 0.522 for diesel and biodiesel, respectively.

For the conditions of experimental studies in a single-cylinder engine [8] (gas pressure 63 bars, fuel temperature $95{ }^{\circ} \mathrm{C}$, initial air temperature $910 \mathrm{~K}$ ), the adiabatic flame temperatures for various fuels and constituent components (molecules) of biodiesel fuel are shown in Table 2.

Consequently, the adiabatic flame temperature for components (molecules) of biodiesel is lower than for diesel fuel. Hence, one can expect lower flame temperatures for biodiesel (B100) than for diesel.

It was assumed [12] that the average temperature of gases in the cylinder during the fuel combustion will be $80^{\circ} \mathrm{K}$ higher than the temperature obtained for an ideal cycle. This assumption leads to the following calculation formula for the adiabatic flame temperature $T_{f}$ :

$T_{f}=298.15 \cdot r^{0.3}+80$,

where $r$ is the compression factor.

The adiabatic flame temperature obtained as a result of calculations by Equation (5) during the combustion of diesel fuel, which is $783.6 \mathrm{~K}$ (when using the compression factor $\mathrm{r}=17.5$ ), seems to be too low comparing to adiabatic flame temperature $\mathrm{T}_{\mathrm{ad}}$ (see Table 2). 


\subsection{Influence of the fuel density}

The biodiesel density is greater than that diesel. Modelling the density of biodiesel, as well as the molecules, from which this fuel is composed, are described in [13]. Vaporization of biodiesel fuel is discussed in detail in [14]. Influence of the fuel density on nitrogen oxide emissions is considered in [13]. Atomization of the high density fuels is inferior to low density fuels, resulting in an increase of the diameter of the fuel droplets. This increases the physical delay in ignition of the fuel, which is the time from the start of fuel injection until the chemical reaction conditions are reached. During that period, the fuel is atomized, evaporated, mixed with air and the temperature rises to the autoignition temperature. A large physical delay increases the maximum pressure during the initial part of the combustion process; therefore, the maximum temperature also increases, which, in turn, increases the NOx concentration.

In this work, the technique described in [13-14] is used for calculation of the diesel fuel components (molecules) density.

\subsection{Influence of the fuel ignition delay}

Modeling the ignition delay for a molecule of biodiesel fuel with the number of carbon atoms equal to 10 , without double bonds (C10: 0) at a pressure of $20 \mathrm{~atm}$, which is a part of biodiesel fuel, was performed in [17]. It was concluded that the ignition delay depends on the cetane number only at low and medium temperatures and at high temperatures the ignition delay is independent of the cetane number.

The following general trend has been observed, which is that fuels with better ignition properties (higher cetane number) have lower NOx emissions, since they have a short lift off length (LOL), which means a richer mixture and less heat released during the fuel ignition [9]. Fuels with a higher cetane number tend to be more saturated, that is, they have a lower $\mathrm{C} / \mathrm{H}$ ratio and lower adiabatic temperatures flame, which means less nitrogen oxide emissions.

The ignition delay of biodiesel fuel molecules was estimated from the dependences given in [17].

\section{Modelling of nitrogen oxide emissions for stationary engines and automobile engines}

In [12], the modelling of nitrogen oxides for a stationary engine and an automobile engine are considered separately. Calculation of nitrogen oxide emissions ( $\mathrm{ppm}$ ) for automobile engines can be performed using the following correlation [12]:

$$
\begin{aligned}
& N E I=20956.69 \cdot p_{f}\left[1+C\left(\begin{array}{c}
-9.91 / 1000 L^{2}+ \\
1.608 L-18.431
\end{array}\right)\right] \\
& \cdot \exp (2.9 \cdot I D-19.627) \cdot \exp \left(4626.44 / T_{f l}\right)
\end{aligned}
$$

where:

$p_{f}$ is the fuel density, $\left[\mathrm{kg} / \mathrm{m}^{3}\right]$,

$L$ is the load, [\%],

$I D$ is the ignition delay, [ms],

$T_{f l}$ is the flame temperature, $[\mathrm{K}]$,

$C=1$ for load conditions, [\%] $(C=0-$ without load $)$.

Calculation of the nitrogen oxide emissions (ppm) for a stationary engine:

$$
\begin{aligned}
& N E I=20956.69 \cdot p_{f}\left[1+C\left(\begin{array}{l}
-5.740 / 1000 L^{2}+ \\
0.0995 L-0.603
\end{array}\right)\right] \\
& \cdot \exp (0.948 \cdot I D-18.83) \cdot \exp \left(4626.44 / T_{f l}\right) .
\end{aligned}
$$

Without considering the load, formulas are simplified. form:

For a stationary engine, Equation (6) takes the

$$
\begin{aligned}
& N E I=20956.69 \cdot p_{f} \cdot \exp (0.948 \cdot I D-18.83) . \\
& \cdot \exp \left(4626.44 / T_{f l}\right) .
\end{aligned}
$$

For an automobile engine, Equation (7) takes the form:

$$
\begin{aligned}
& N E I=20956.69 \cdot p_{f} \cdot \exp (2.9 \cdot I D-19.627) . \\
& \cdot \exp \left(4626.44 / T_{f l}\right) .
\end{aligned}
$$

As can be seen from the comparison of Equations (6), (8) and (7), (9), the difference is contained in the ignition delay of the fuel. Researchers [12] believed that the ignition delay of the same fuel should be different in the conditions of stationary engines and automobile engines. They made such a conclusion by comparing the emissions of nitrogen oxides of these engines. The ignition delay in [12] was found based on the NOx emissions, as well as on the assumption that the activation energy of NOx formation is constant for all fuels and is equal to $38465.61 \mathrm{~J} / \mathrm{mol}$.

Tables 3 and 4 show the ignition delays and NOx emissions at various loads when using a stationary engine and an automobile engine, respectively. Tables contain data that was obtained in [12]. The comparison of NOx emissions for diesel and biodiesel (crude rice bran oil methyl ester - CRBME) is shown in Figure 1.

As can be seen from Figure 1, NOx emissions increase with increasing load for both diesel and biodiesel. The maximum emissions for the two fuels are observed in the load range of $60-80 \%$. In no-load mode, as shown in a study [12], biodiesel has lower NOx emissions than diesel. 
Table 3 Ignition delay (ID) and NOx emissions (stationary engine)

\begin{tabular}{ccccc}
\hline Load, $\%$ & Diesel, ID $[\mathrm{ms}]$ & NOx $(\mathrm{ppm})$ & Biodiesel (CRBME) & NOx (ppm) \\
\hline 0 & 1.74 & 252 & 1.68 & 246 \\
25 & 1.72 & 478 & 1.64 & 453 \\
50 & 1.67 & 534 & 1.59 & 825 \\
75 & 1.63 & 993 & 1.55 & 952 \\
100 & 1.59 & 940 & 1.52 & 986 \\
\hline
\end{tabular}

Table 4 Ignition delay (ID) and NOx emissions (automobile engine)

\begin{tabular}{ccccc}
\hline Load, $\%$ & Diesel, ID [ms] & NOx (ppm) & Biodiesel & NOx (ppm) \\
\hline 0 & 0.96 & 273 & 0.92 & 281 \\
20 & 0.52 & 811 & 0.501 & 847 \\
40 & 0.317 & 1041 & 0.304 & 1106 \\
60 & 0.207 & 1343 & 0.198 & 1475 \\
80 & 0.143 & 1384 & 0.137 & 1565 \\
100 & 0.104 & 1116 & 0.099 & 1192 \\
\hline
\end{tabular}

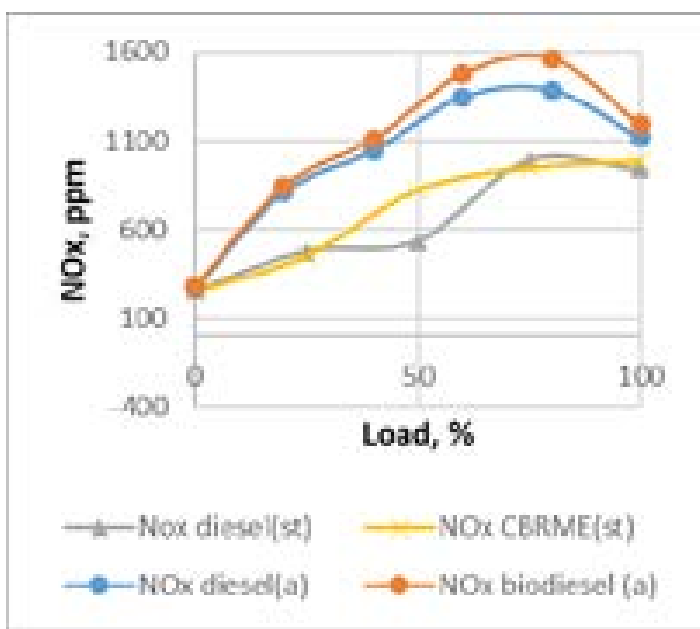

Figure 1 Comparison of the NOx emissions for diesel and biodiesel (CRBME) for the stationary engine (st) and car engine (a)

\section{Modelling of nitrogen emissions for the composed biodiesel components.}

Of great interest for modelling are not only the emissions of nitrogen oxides from biodiesel, but the components from which this fuel is composed, as well. Most often, biodiesel is made from vegetable oils with addition of the methyl alcohol. Therefore, methyl esters of fatty acids are the most common constituents of biodiesel, the names, formulas and cetane number $(\mathrm{CN})$ of which are shown in Table 5. The presence of oxygen in biodiesel (about 11\%) is also considered to be one of the reasons for the increase in NOx emissions [19].

The third column of Table 5 shows the designation of methyl esters, where the numbers of carbons in fatty acids and numbers of double bonds are shown by numbers to the left and the right of ":", respectively. The biodiesel ignition delay can be calculated based on the DCN (Derived Cetane Number) obtained from the IQT (Ignition Quality Tester) test. In [20], the DCN was calculated based on the ID value according to the following formula: $\mathrm{DCN}=4.460+186.6 / \mathrm{ID}$.

From here one gets the ID value: ID $=186.6 /(\mathrm{DCN}$ - 4.460).

The latter formula was used to calculate the ID of the biodiesel components.

Verification of Equation (8), as applied to components of biodiesel fuel with the values of activation temperature and flame temperatures, given in [12], showed unrealistically large NOx emissions. Therefore, for the calculations, the flame temperatures $\left(\mathrm{T}_{\mathrm{ad}}\right)$ were chosen, which are given in Table 2.

The activation energy of biodiesel fuel $(38.465 \mathrm{~kJ} /$ mol), which is adopted in [12], also needs to be clarified. In work [13], the activation energies of biodiesel and its components were analyzed. The activation energies for C18:1M, C10: $0 \mathrm{M}$ and C12:0 M molecules are 67, 151 and $193 \mathrm{~kJ} / \mathrm{mol}$, respectively. The activation energy of $67 \mathrm{~kJ} /$ mol was taken for calculations, which gives an activation temperature of $8058.38 \mathrm{~K}$ in comparison to $4626.44 \mathrm{~K}$, 
Table 5 Values of cetane numbers of biodiesel fuel components obtained by different methods

\begin{tabular}{|c|c|c|c|c|c|}
\hline Biodiesel components & Formula & Notation & CN (experiment) [20] & $\begin{array}{l}\text { DCN (experiment } \\
\text { IQT) [20] }\end{array}$ & $\begin{array}{c}\mathrm{CN} \text { (modelling) } \\
\text { [13] }\end{array}$ \\
\hline methyl laurate & $\mathrm{C} 13 \mathrm{H} 26 \mathrm{O} 2$ & $(\mathrm{C} 12: 0 \mathrm{M})$ & $66.7 ; 66.3 ; 66.7$ & - & 61.1 \\
\hline methyl myristate & C15H30O2 & $(\mathrm{C} 14: 0 \mathrm{M})$ & $73.5 ; 66.2$ & 75.8 & 69.9 \\
\hline methyl palmitate & C17H34O2 & $(\mathrm{C} 16: 0 \mathrm{M})$ & $74.5 ; 74.3 ; 74.3$ & 85.9 & 74.4 \\
\hline methyl stearate & C19H38O2 & $(\mathrm{C} 18: 0 \mathrm{M})$ & $86.9 ; 75.6$ & 95.6 & 76.3 \\
\hline methyl palmitoleate & C17H32O2 & $(\mathrm{C} 16: 1 \mathrm{M})$ & - & 56.6 & 51 \\
\hline methyl oleate & $\mathrm{C} 19 \mathrm{H} 36 \mathrm{O} 2$ & $(\mathrm{C} 18: 1 \mathrm{M})$ & 56.0 & $59.8 ; 56.6 ; 59.3$ & 57.2 \\
\hline methyl linoleate & C19H34O2 & $(\mathrm{C} 18: 2 \mathrm{M})$ & 41.7 & $43.9 ; 38.2$ & 36.8 \\
\hline methyl linolenate & $\mathrm{C} 19 \mathrm{H} 32 \mathrm{O} 2$ & $(\mathrm{C} 18: 3 \mathrm{M})$ & $45.9 ; 23$ & 37.0 & 21.6 \\
\hline methyl $\alpha$-linolenate & $\mathrm{C} 19 \mathrm{H} 32 \mathrm{O} 2$ & - & - & 22.7 & - \\
\hline methyl $\gamma$-linolenate & $\mathrm{C} 19 \mathrm{H} 32 \mathrm{O} 2$ & - & - & 29.2 & - \\
\hline
\end{tabular}

Table 6 Calculated NOx emissions (NEI) of different biodiesel component for automotive engine and stationary engine

\begin{tabular}{ccccccc}
\hline Component & Density & DCN & ID & $\mathrm{T}_{\text {ad }}, \mathrm{K}$ & $\begin{array}{c}\text { NEI (ppm) stationary engine } \\
\text { Equation (10) }\end{array}$ & $\begin{array}{c}\text { NEI (ppm) - automotive } \\
\text { engine Equation (11) }\end{array}$ \\
\hline C14:0M & 865.0363 & 75.8 & 2.62 & 2555 & 33.67 & 43.73 \\
C16:0 M & 863.2509 & 85.9 & 2.29 & 2660 & 21.81 & 24.87 \\
C18:0 M & 861.8251 & 56.6 & 3.58 & 2665 & 73.39 & 140.40 \\
C18:1M & 874.2283 & 58.1 & 3.48 & 2670 & 67.32 & 123.72 \\
C18:2 M & 886.6315 & 41.05 & 5.10 & 2680 & 313.90 & 1106.73 \\
C18:3 M & 899.0347 & 37 & 5.73 & 2700 & 568.16 & 2585.49 \\
SME & $877^{*}$ & $49.9^{*}$ & 4.10 & 2700 & 118.43 & 280.09 \\
\hline
\end{tabular}

* The cetane number and density values for soybean biodiesel fuel (SME) are taken from [9].

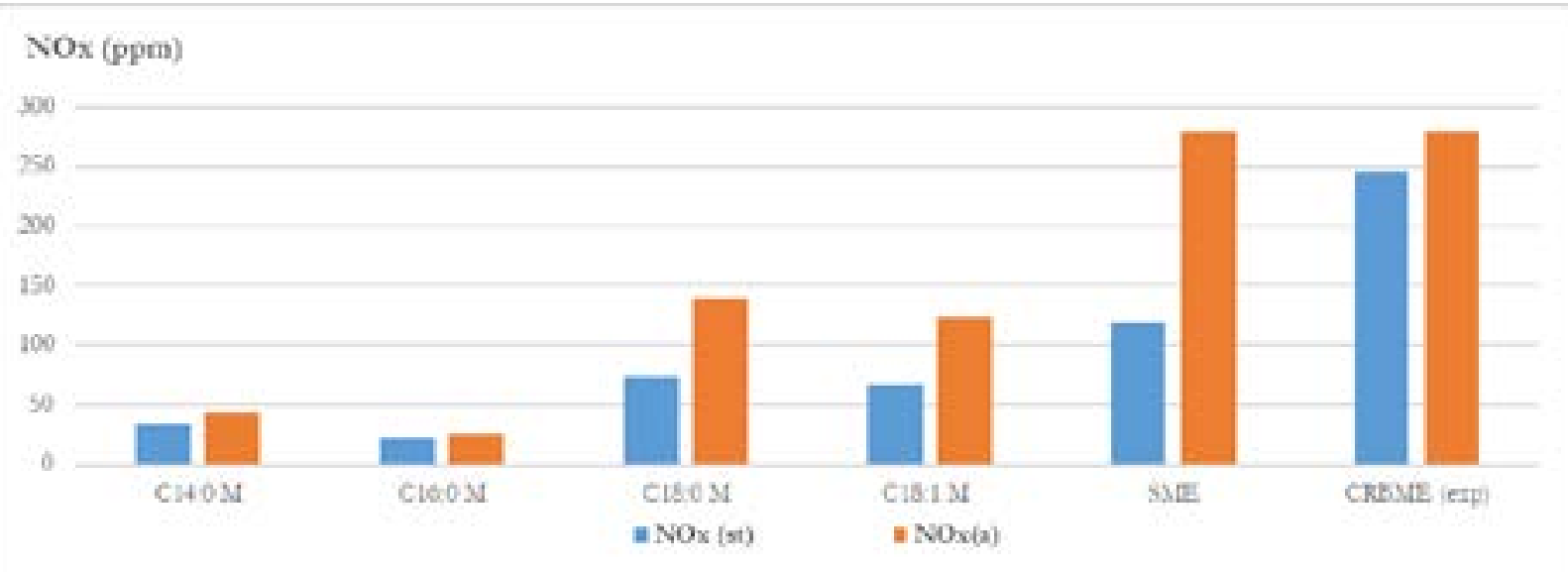

Figure 2 Comparison of calculated NOx of biodiesel components and SME with experimental NOx of CBRME for the stationary engine (st) and automobile engine (a)

which was adopted in [12]. To simulate NOx emissions in an automotive engine, the multiplier containing the ID has also been changed to better match the experimental data. Given the above changes, emissions of nitrogen oxides (ppm) of biodiesel components (no-load mode) can be modelled using the following formulas:

- in a stationary engine:

$N E I=20956.69 \cdot p_{f} \cdot \exp (0.948 \cdot I D-18.83)$

$\cdot \exp \left(8058.38 / T_{f l}\right)$,
- for automotive engine:

$N E I=20956.69 \cdot p_{f} \cdot \exp (1.35 \cdot I D-19.62)$ $\cdot \exp \left(8058.38 / T_{f l}\right)$.

Results of calculating the nitrogen oxides of biodiesel components, as well as SME (soybean oil methyl ester) according to Equations (10) and (11), are shown in Table 6.

The methyl ester density, shown in Table, 6 was estimated based on the following formulas [21]: 


$$
\begin{aligned}
\rho_{l} & =\rho_{l 0}-\alpha_{T}(T-288.15), \\
\rho_{l 0} & =851.471+\frac{250.718 D B+280.899}{1.214+n_{\text {acid }}}, \\
\alpha_{T} & =\frac{7.536}{\ln \left(n_{\text {acid }}\right)+3.584}-0.446,
\end{aligned}
$$

where $D B$ is numbers of double bonds, $n_{\text {acid }}$ is the number of carbons in fatty acids.

Figure 2 shows values of the nitrogen oxides of components and SME, calculated by Equations (10) and (11) in comparison to experimental data [12] for CBRME.

\section{Conclusions}

1. Flame temperature, ignition delay and fuel density are important factors influencing the formation of nitrogen oxides in the internal combustion engine of motor vehicles.
2. Emissions of nitrogen oxides increase with increasing load. In the no-load mode, biodiesel has lower NOx emissions than diesel.

3. Since biodiesel fuels have the lower ignition delay values than diesel fuel, this is the factor that reduces the nitrogen oxide emissions.

4. An increase in the flame temperature contributes to formation of more nitrogen oxide emissions. Calculation of the flame temperature of diesel biofuels and their components requires additional research.

5. Approximations were proposed and nitrogen oxide emissions for the components (methyl esters of fatty acids) of biodiesel are calculated based on the DCN value for these of the components.

6. The approximations for modelling of NOx emission for biodiesel components (methyl esters of fatty acids) were proposed and values of NOx for both the stationary engine and automotive engine were calculated based on the DCN value of the components.

\section{References}

[1] PUKALSKAS, S., KRIAUCIUNAS, D., RIMKUS, A., PRZYBYLA, G., DROZDZIEL, P., BARTA, D. Effect of hydrogen addition on the energetic and ecologic parameters of an SI engine fuelled by biogas. Applied Sciences [online]. 2021, 11(2), 742. ISSN: 2076-3417. Available from: https://doi.org/10.3390/app11020742

[2] PUNOV, P., GECHEV, T., MIHALKOV, S., PODEVIN, P., BARTA, D. Experimental study of multiple pilot injection strategy in an automotive direct injection diesel engine. MATEC Web of Conferences [online]. 2018, 234, 03007. ISSN 2261-236X. Available from: https://doi.org/10.1051/matecconf/20182340 07

[3] HONIG, V. Specifications of wear of oils in two-fuel systems. Manufacturing Technology [online]. 2018, 18(4), p. 567-571. ISSN 1213-2489. Available from: https://doi.org/10.21062/ujep/139.2018/a/1213-2489/MT/18/4/567

[4] HOLUBEK, M., PEXA, M., PAVLU, J., CEDIK, J., VESELA, K., KUCHAR, P. Analysis of the influence of fuel on oil charge and engine wear. Manufacturing Technology [online]. 2019, 19(1), p. 64-70. ISSN 1213-2489. Available from: https://doi.org/ 10.21062/ujep/245.2019/a/1213-2489/MT/19/1/64

[5] FOMIN, O., AKIMOVA, A., AKIMOVA, J., MASTEPAN, A. The criteria choice of evaluating the effectiveness of the process and automatic control systems. Procedia Computer Science [online]. 2019, 149, p. 246-251. ISSN 1877-0509. Available from: https://doi.org/10.1016/j.procs.2019.01.130

[6] FOMIN, O., MASTEPAN, A., BONDARENKO, A., LUTAI, S. Electromagnetic compatibility of systems autonomous voltage inverter - induction motor with a power source. Procedia Computer Science [online]. 2019, 149, p. 278-281. ISSN 1877-0509. Available from: https://doi.org/10.1016/j.procs.2019.01.135

[7] DIZO, J., BLATNICKY, M. Use of multibody system dynamics as a tool for rail vehicle behaviour diagnostics. Diagnostyka. 2016, 17(2), p. 9-16. ISSN 1641-6414.

[8] Biofuels consumption for transport in Slovakia in 2015-2019 - Statista [online]. Available from: https://www.statista.com/statistics/613307/biofuels-consumption-transport-slovakia/

[9] MUELLER, C. J., BOEHMAN, A. L., MARTIN G. S. An experimental investigation on the origin of increasing NOx emissions when fuelling a heavy-duty compression engine with soy biodiesel. $S A E$ International Journal of Fuels and Lubricants [online]. 2009, 2(1), p. 789-816. ISSN 1946-3952. Available from: https://doi.org/10.4271/2009-01-1792

[10] SCHONBORN, A., LADOMMATOS, N., WILLIAM, S. J., ALLAN, R., ROGERSON, J. The influence of molecular structure of fatty acid monoalkyl esters on diesel combustion. Combustion and Flame [online]. 2009, 156(7), p. 1396-1412. ISSN 0010-2180. Available from: https://doi.org/10.1016/j.combustflame.2009.03.011

[11] KAYA, T., KUTLAR, O. A., TASKIRAN, O. O. Evaluation of the partially premixed compression ignition combustion with diesel and biodiesel blended diesel at part load condition. Engineering Science and Technology, an International Journal [online]. 2021, 24(2), p. 458-468. ISSN 2215-0986. Available from: https://doi.org/10.1016/j.jestch.2020.07.011 
[12] SARAVANAN, S., NAGARAJAN, G., ANAND, S., SAMPATH, S. Correlation for thermal NOx formation in compression ignition (CI) engine fuelled with diesel and biodiesel. Energy [online]. 2012, 42(1), p. 401-410. ISSN 0360-5442. Available from: https://doi.org/ 10.1016/j.energy.2012.03.028

[13] KOLODNYTSKA, R. V. Evaporation and combustion processes of diesel biofuel in internal combustion engines (in Ukrainian). Zhytomyr: Zhytomyr State Technological University, 2018. ISBN 978-966-683-499-0.

[14] KOLODNYTSKA, R. V. Spraying of diesel fuel and biofuel in internal combustion engines. (in Ukrainian). Zhytomyr: Zhytomyr State Technological University, 2017. ISBN 978-966-683-489-1.

[15] GUTAREVICH, Y. F., KAREV, S. V. Calculations effect of exhaust gas recirculation on formation of nitrogen oxides in the application of the combined method of power control of modern gasoline engine (in Ukrainian). Visnyk NTU. 2012, 26, p. 133-138. ISSN 2413-4295.

[16] KOLODNYTSKA, R. V. Calculations effect of exhaust gas recirculation on formation of nitrogen oxides in the application of the combined method of power control of modern gasoline engine (in Ukrainian). Visnyk of Zhytomyr Polytechnic State University, Technical Sciences. 2018, 2(82), p. 63-68. ISSN 1728-4260.

[17] KOLODNYTSKA, R. V., KRAVCHENKO, A. P. Modelling the ignition delay of diesel biofuel in the internal combustion engine of road transport (in Ukrainian). In: International Scientific and Practical Conference dedicated to the 90th anniversary of the Kharkiv Automobile and Highway University and the 90th anniversary of the Automobile Faculty "Modern trends in the Development of Road Transport and Industrial Engineering": proceedings. 2020. p. 239-241.

[18] WANG, W. G., LYONS, D. W., CLARK, N. N., GAUTAM, M., NORTON, P. M. Emissions from nine heavy trucks furled by diesel and biodiesel blend without modification. Environmental Science and Technology [online]. 2000, 34(6), p. 933-939. ISSN 0013-936X. Available from: https://doi.org/10.1021/es981329b

[19] KUMAR, A., KIM, D.-S., OMIDVARBORNA, H., YARLAGADDA, M., KUPPILI, S. K., SAWTARIE, N. M. Experimental modelling of NOx and PM generation from combustion of various biodiesel blends for urban transport buses. MNTRC project 1245. Toledo: The University of Toledo, 2016.

[20] YANOWITZ, J., RATCLIFF, M. A., MCCORMICK, R. L., TAYLOR, J. D., MURPHY, M. J. Compendium of experimental cetane numbers. Technical report NREL/TP-5400-67585. Golden: National Renewable Energy Laboratory, 2017.

[21] SAZHIN, S. S., AL QUBEISSI, M., KOLODNYTSKA, R., ELWARDANY, A. E., NASIRI, R., HEIKAL, M. R. Modelling of biodisel fuel droplet heating and evaporation. Fuel [online]. 2014, 115, p. 559 - 572. ISSN 0016-2361. Available from: https://doi.org/10.1016/j.fuel.2013.07.031 